\title{
EFEK WAKTU HENTI PENDARAHAN (BLEEDING TIME) DAUN BANDOTAN (Ageratum conyzoides L.) PADA MENCIT (Mus musculus)
}

\author{
M. Sidrotullah ${ }^{*}$ \\ ${ }^{1}$ Program Studi Farmasi DIII, Fakultas Ilmu Kesehatan, Universitas Nahdlatul Wathan Mataram, \\ Jl. Merdeka Raya, Karang Pule, Mataram
}

* Penulis Korespondensi. Email: sidrotullah85@gmail.com

\section{ABSTRAK}

Bandotan (Ageratum conyzoides L) merupakan tanaman yang berfungsi sebagai agen hemostatik eksternal Bleeding time merupakan waktu saat mulai terjadinya perdarahan hingga terbentuk sumbat trombosit dan vasokontriksi pembuluh darah sehingga darah berhenti mengalir. Penelitian ini bertujuan untuk mengetahui efektivitas dan konsentrasi ekstrak etanol daun bandotan (Ageratum conyzoides L.) dalam menghentikan pendarahan pada mencit jantan dengan menggunakan penelitian eksperimental. Metode yang digunakan adalah Metode Duke. Ekstraksi daun bandotan dilakukan dengan cara maserasi menggunakan pelarut etanol 96\% kemudian diuji skrining fitokimia. Hasil skrining menyatakan positif mengandung flavonoid dan tannin. Hewan uji yang digunakan sebanyak 25 ekor mencit, dibagi dalam 5 kelompok. Kelompok 1 diberi Aquadest, Kelompok 2 diberi obat Epinefrin 1mg/1ml, Kelompok 3 diberikan ekstrak etanol daun bandotan 10\%, Kelompok 4 diberikan ekstrak etanol daun bandotan 20\%, dan kelompok 5 diberikan ekstrak etanol daun bandotan $40 \%$. \%. Data dianalisis dengan uji statistik ANNOVA $(\mathrm{p}<0,01)$ Hasil analisis menunjukkan perbedaan yang signifikan waktu henti pendarahan dari setiap kelompok perlakuan dan dilanjutkan dengan uji LSD (Least Significant Different). Konsentrasi ekstrak daun bandotan yang memiliki efektivitas dalam menghentikan pendarahan terbaik adalah konsentrasi $40 \%$.

Kata Kunci: Ageratum conyzoides L, Waktu Henti Pendarahan

\begin{tabular}{ccc} 
Diterima: & Disetujui: & Online: \\
9-02-2021 & $1-03-2021$ & $5-03-2021$ \\
\hline
\end{tabular}

ABSTRACT

Ageratum conyzoides $\mathrm{L}$ is a plant that functions as an external hemostatic agent. Bleeding time is the time when bleeding begins to form a platelet plug and vasoconstriction of blood vessels so that blood stops flowing. This study aims to determine the effectiveness and concentration of the ethanol extract of Ageratum conyzoides L leaves in stopping bleeding on male mice through an experimental research. The method employed was the Duke Method. Ageratum conyzoides L leaf extraction was carried out by maceration using $96 \%$ ethanol solvent then tested by phytochemical screening. The screening result was tested positive for flavonoids and tannins. The tested animals used were 25 mice which were divided into five groups. Group 1 was given aquadest, group 2, $1 \mathrm{mg} / 1 \mathrm{ml}$ of epinephrine drug, group 3, 10\% ethanol extract of Ageratum conyzoides leaves, group 4, 20\% Ageratum conyzoides leaf ethanol extract, and group 5 was given $40 \%$ ethanol extract. Then the data were analyzed using the ANNOVA statistical test $(\mathrm{p}<0.01)$. The results of the analysis showed a significant difference in the 
bleeding stop time of each treatment group and continued with the LSD (Least Significant Different) test. The best concentration of Ageratum conyzoides leaf extract that has the best effectiveness in stopping bleeding was a concentration of $40 \%$.

Copyright $\odot$ 2021Jsscr. All rights reserved

Keywords: Ageratum conyzoides L.; Bleeding Stop Time

$\begin{array}{lcc}\text { Received: } & \text { Accepted: } & \text { Online: } \\ \text { 2021-02-9 } & 2021-03-1 & 2021-03-5\end{array}$

\section{Pendahuluan}

Ramuan obat yang berasal dari tumbuh-tumbuhan sudah sejak lama diciptakan oleh nenek moyang kita guna meningkatkan kesehatan hidup dan mengobati penyakit. Naskah kuno yang tersebar diseluruh Indonesia menulis tradisi-tradisi tersebut. Diantaranya terdapat beberapa jenis ramuan untuk menyembuhkan berbagi penyakit yang menyerang masyarakat.

Pengobatan herbal masih menjadi pilihan utama baik dinegara maju dan dinegara berkembang, menurut World Health Organization (WHO) sebanyak 80\% penduduk dinegara berkembang dan $65 \%$ penduduk dinegara maju memilih menggunakan obat tradisional [1]. Sebanyak $40 \%$ penduduk indonesia menggunakan obat tradisional dan sebanyak $70 \%$ berada didaerah pedesaan [2]. Salah satu pemanfaatan obat herbal yaitu dalam menghentikan perdarahan.

Kehidupan organisme dipengaruhi oleh berfungsi normalnya sistem penghentian darah, karena luka dengan ukuran yang kecil pun akan mudah mengalami pendarahan yang parah apabila sistem penghentian darah mengalami gangguan atau terganggu [3]. Ketika permukaan tubuh mengalami luka, tubuh akan mengeluarkan darah, tubuh yang normal ketika mengalami luka setelah beberapa saat darah akan berhenti mengalir, sedangkan pada luka yang besar dapat menyebabkan pendarahan yang banyak sehingga mengakibatkan kekurangan darah bahkan sampai menyebabkan kematian, maka harus sesegera mungkin melakukan penghentian pendarahan. Tubuh mempunyai sistem untuk menyumbat dan memperbaiki sistem sirkulasi, salah satunya adalah melalui hemostatis. Hemostatis merupakan proses penghentian pendarahan pada pembuluh darah yang cedera [4].

Pada lingkungan pertanian, tanaman bandotan (Ageratum conyzoides L.) disebut sebagai gulma pembawa virus yang sulit dikendalikan perkembangannya. Tanaman bandotan sering dibuang bahkan dibakan karena dianggap dapat menyebabkan tanaman lain pada suatu daerah itu berkurang. Tetapi tanaman bandotan yang sering disebut sebagai tanaman gulma ini menyimpan berbagai manfaat, salah satunya tanaman ini dapat dijadikan sebagai obat untuk luka dengan menghambat pendarahan atau menghentikan pendarahan. Bandotan merupakan tanaman yang berfungsi sebagi agen hemostatik eksternal [5].

Berdasarkan hasil skrining fitokimia, daun bandotan memiliki senyawa metabolit sekunder yaitu flavonoid dan tannin [6]. Tanin bekerja melalui efek astringennya [7]. Selain tanin, flavonoid juga terkandung dalam tanaman bandotan yang dapat memberikan efek sebagai agen hemostasis. Flavonoid berefek dengan cara vasokontriksi dalam menghentikan pendarahan dan Flavonoid yang dinyatakan sebagai quersetin 
dapat meningkatkan jumlah trombosit yang fungsinya sangat penting dalam tubuh yaitu menghentikan perdarahan akibat pecahnya pembuluh darah [8].

Berdasarkan uraian tentang efektifitas daun bandotan dalam menghentikan perdarahan tersebut serta didukung dengan pengalaman empiris dari masyarakat, Peneliti bermaksud untuk melihat efektivitas daun bandotan (Ageratum conyzoides L.) dalam menghentikan pendarahan (Bleeding time) yang diujikan pada mencit jantan (Mus musculus) yang dijadikan sebagai hewan uji.

2. Metode

Metode penelitian yang digunakan adalah metode experimental yang merupakan penelitian laboratorium untuk melihat efektivitas dari ekstrak Daun Bandotan (Ageratum conyzoides L.) dalam menghentikan pendarahan (Bleeding Time) yang diujikan pada mencit jantan (Mus muscullus).

2.1. Parameter Penelitian

Parameter penelitian ini dilakukan dengan menggunakan Metode Duke. Metode Duke merupakan metode perhitungan waktu perdarahan dengan membuat luka pada ekor hewan uji. Prinsip kerja dari metode ini yaitu menghitung waktu perdarahan sejak darah mulai keluar sampai darah tidak dapat terserap dikertas serap. Setiap 30 detik darah yang keluar diserap dengan kertas serap dengan catatan jangan sampai menyentuh luka. Nilai rujukan Metode Duke yaitu 1-3 menit [9].

\subsection{Alat dan Bahan}

Alat-alat yang digunakan dalam penelitian ini yaitu alat maserasi, batang pengaduk, gelas kimia, gelas ukur, tabung reaksi, rak tabung reaksi, neraca analitik, stopwatch, Surgical Scissors.

Bahan-bahan yang digunakan dalam penelitian ini yaitu aquadest, etanol 96\%, sampel daun bandotan (Ageratum conyzoides L.), kertas saring, kertas serap, epinefrin 1:1000, makanan dan minuman hewan uji (pelet, jagung, mentimun dan air putih).

\subsection{Prosedur Penelitian}

a. Pengolahan Sampel

Sampel daun bandotan (Ageratum conyzoides L.) dipanen pada pagi hari saat tumbuhan masih segar, kemudian dilakukan sortasi basah dan pencucian menggunakan air mengalir untuk menghilangkan kotoran-kotoran yang masih menempel pada daun bandotan, kemudian sampel dikeringkan tetapi tidak terpapar langsung oleh sinar matahari. Selanjutnya dilakukan sortasi kering untuk memisahkan dari daun yang rusak selama pengeringan. Langkah terakhir yaitu daun bandotan yang telah disortasi kering kemudian dibuat dalam bentuk serbuk.

\section{b. Pembuatan Ekstrak}

Simplisia daun bandotan dilakukan dengan cara maserasi. Bahan yang telah kering kemudian dihaluskan menggunakan blender hingga berbentuk serbuk. Simplisia ekstrak daun Bandotan(Ageratum conyzoides L.), yang telah dihaluskan, ditimbang 500 gram kemudian diekstraksi menggunakan etanol 96\%. Serbuk simplisia daun bandotan sebanyak 500 gram dimasukkan kedalam toples kaca kemudian direndam dengan pelarut etanol $96 \%$ sebanyak $3750 \mathrm{ml}$ ditutup menggunakan aluminium foil dan dibiarkan selama lima hari sambil sesekali diaduk. Setelah lima hari, sampel yang 
direndam tersebut disaring dengan menggunakan kertas saring sehingga menghasilkan filtrat kemudian dipekatkan dengan menggunakan rotary vacuum evaporator hingga diperoleh ekstrak kental dan dihitung persen rendamennya.

\subsection{Uji Skrining Fitokimia}

Hasil ekstrak etanol daun bandotan kemudian diuji skrining fitokimia untuk mengidentifikasi adanya kandungan senyawa flavonoid dan tannin pada sampel tersebut

a. Uji Flavonoid

Sebanyak 1 gram ekstrak daun bandotan dilarutkan kedalam $2 \mathrm{ml}$ etanol, kemudian ditambahkan serbuk $\mathrm{Mg}$ dan $\mathrm{HCl}$ pekat sebanyak 5 tetes. Adanya senyawa flavonoid ditunjukkan dengan terbentuknya warna merah atau jingga.

b. Uji Tannin

Sebanyak 1 gram ekstrak daun bandotan dimasukkan kedalam tabung reaksi, kemudian ditambahkan FeCL3 1\% sebanyak 2-3 tetes. Sampel positif mengandung tannin bila mengalami perubahan warna menjadi hijau kehitaman.

\subsection{Pengujian Bleeding Time}

Hewan uji yang digunakan adalah Mencit berumur 2-3 bulan, dengan berat badan 2030 gram. Penentuan jumlah sampel ditentukan berdasarkan rumus Federer yaitu (n-1) $(\mathrm{t}-1) \geq 15$. Hewan uji yang digunakan dalam penelitian ini adalah 25 ekor mencit jantan (Mus musculus). Hewan uji dikelompokkan menjadi 5 kelompok, setiap kelompok terdiri dari 5 ekor mencit yaitu kelompok 1 (kontrol negatif diberikan aquadest), kelompok 2 sebagai kontrol positif diberikan epinefrin 1:1000 $(1 \mathrm{mg} / 1 \mathrm{ml})$, kelompok 3 (perlakuan 1 ekstrak dengan konsentrasi 10\%), kelompok 4 (perlakuan 2 ekstrak dengan konsentrasi $20 \%$ ) dan kelompok 5 (perlakuan 3 ekstrak dengan konsentrasi 40\%) .

Selanjutnya ekor mencit diberi tanda sepanjang $2 \mathrm{~cm}$ dari ujung ekor. Ekor mencit dianastesi secara topikal menggunakan ethyl chlorida disekitar ekor yang akan dilukai. Selanjutnya ekor mencit dipotong sepanjang $3 \mathrm{~mm}$ menggunakan surgical scissor. Setelah dipotong, ekor mencit dicelupkan kedalam masing-masing kelompok perlakuan selama 5 detik, Setiap darah yang keluar dari ekor mencit diteteskan dikertas serap (tanpa menyentuh luka) setiap 30 detik sampai darah berhenti. Waktu mulai diukur menggunakan stopwatch ketika darah terserap pertama kali sampai darah berhenti dengan ditunjukan tidak ada lagi darah yang terserap pada kertas saring. Interval waktu saat darah keluar pertama kali hingga darah berhenti keluar adalah waktu perdarahan (bleeding time) [10].

\section{Hasil dan Pembahasan.}

\subsection{Ekstaksi dan Penelusuran senyawa Fitokimia}

Proses ekstraksi daun Bandotan (Ageratum conyzoides L.) sebesar 11,01\% presentase ini menunjukan bahwa proses penyarian berlangsung baik, presentase rendamen dapat dikatakan sempurna jika hasilnya berkisar 10-15\% [11].

\begin{tabular}{cccc}
\hline Senyawa & Pereaksi & Hasil Uji & Keterangan \\
\hline Flavonoid & $\mathrm{Mg}+\mathrm{HCl}$ Pekat & Merah & $\begin{array}{c}\text { Positif Flavonoid } \\
(+)\end{array}$ \\
\hline Tannin & $\mathrm{FeCl}_{3}$ & Hijau Kehitaman & Positif Tanin $(+)$ \\
\hline
\end{tabular}

Berdasarkan hasil skiring fitokimia menunjukkan sampel daun bandotan (Ageratum conyzoides L.) positif mengandung senyawa Flavonoid (tabel 1). Hal ini sesuai dengan 
penelitian lain yang melaporkan bahwa dalam daun bandotan mengandung zat akif berupa flavonoid dan tannin [6].

\subsection{Pengukuran Bleeding Time}

Bleeding time menunjukkan hasil pengukuran rata-rata lama waktu henti pendarahan pada mencit jantan yang dibagi menjadi lima kelompok. Penelitian ini menggunakan parameter metode duke dengan nilai rujukan yaitu 1-3 menit. Trombosit adalah faktor besar dalam proses hemostatis. Dibutuhkan sekitar 60 detik hingga helai fibrin mulai seling diantara luka, sehingga setelah beberapa menit (sesuai standarnya) sumbat trombosit sepenuhnya terbentuk, sedangkan tingkat keparahan perdarahan tergantung pada jumlah faktor pembekuan dalam darah. Semakin sedikit jumlah faktor pembekuan darah, perdarahan akan semakin sulit untuk berhenti atau sebaliknya terjadi pembekuan darah terlalu banyak sehingga yang dapat menganggu sirkulasi darah, kondisi ini disebut dengan darah kental. Salah satu pemeriksaan masa perdarahan adalah dengan proses bleeding time [12]. Adapun hasil pengukuran ditampilkan pada tabel 2.

Tabel 2. Hasil Pengukuran Waktu Henti Pendarahan Pada Luka Ekor Mencit

\begin{tabular}{|c|c|c|c|c|c|c|c|}
\hline \multirow[t]{2}{*}{$\begin{array}{l}\text { Kelompok } \\
\text { Perlakuan }\end{array}$} & \multicolumn{5}{|c|}{$\begin{array}{l}\text { Waktu Henti Pendarahan (Bleeding time) } \\
\text { (Detik) }\end{array}$} & \multirow[t]{2}{*}{$\sum_{\text {(detik) }}$} & \multirow{2}{*}{$\begin{array}{l}\text { Rata-Rata } \\
\text { (detik) }\end{array}$} \\
\hline & 1 & 2 & 3 & 4 & 5 & & \\
\hline Kelompok 1 & 207 & 220 & 198 & 194 & 236 & 1.055 & 210 \\
\hline Kelompok 2 & 68 & 73 & 78 & 77 & 89 & 385 & 77 \\
\hline Kelompok 3 & 150 & 140 & 146 & 178 & 154 & 768 & 153 \\
\hline Kelompok 4 & 120 & 120 & 115 & 112 & 123 & 590 & 118 \\
\hline Kelompok 5 & 90 & 96 & 93 & 90 & 98 & 467 & 93 \\
\hline \multicolumn{8}{|l|}{ Keterangan : } \\
\hline \multicolumn{8}{|c|}{$\begin{array}{ll}\text { Kelompok } 1 & \text { : Diberikan aquadest (kontrol negatif) v/v } \\
\text { Kelompok } 2 & \text { : Diberikan Epinefrin } 1 \mathrm{ml} / 1 \mathrm{mg} \text { (kontrol positif) v/v } \\
\text { Kelompok } 3 & \text { : Diberikan ekstrak etanol daun bandotan } 10 \% \mathrm{v} / \mathrm{v} . \\
\text { Kelompok } 4 & \text { : Diberikan ekstrak etanol daun bandotan } 20 \% \mathrm{v} / \mathrm{v} . \\
\text { Kelompok } 5 & : \text { Diberikan ekstrak etanol daunbandotan } 40 \% \mathrm{v} / \mathrm{v} \\
\sum & \text { : Jumlah }\end{array}$} \\
\hline
\end{tabular}

Hasil pengukuran didapatkan yaitu kelompok 2 (kontrol positif) memiliki kemampuan menghentikan pendarahan lebih cepat dibandingkan dengan kelompok perlakuan lainnya. Pemberian Epinefrin berfungsi sebagai zat hemostatik. Berdasarkan golongan obat hemostatik, epinefrin merupakan golongan obat hemostatik lokal kelompok vasokonstriktor dan dapat digunakan untuk menghentikan pendarahan perdarahan kapiler pada suatu permukaan dengan dosis 1:1000 $(1 \mathrm{mg} / 1 \mathrm{ml})$ [13]. Epinefrin ini bekerja pada reseptor adrenergic $\alpha_{1}$ untuk menimbulkan efek vasokonstriktor pembuluh darah kapiler kulit dengan cara mengurangi ukuran kapiler darah sehingga suplai darah terbatas dan akibatnya akan mengurangi perdarahan dan rembesan cairan [14]. 
Berdasarkan data hasil pengukuran yang ditunjukkan pada tabel 2, ketiga konsentrasi ekstrak etanol daun bandotan memberikan efek dalam menghentikan pendarahan karena masuk dalam range nilai rujukan metode duke yaitu 1-3 menit. Hal ini karena pada daun bandotan mengandung senyawa flavonoid dan tannin yang berperan penting dalam proses hemostatis. Senyawa utama yang dapat berefek sebagai hemostatis adalah tannin dan flavonoid [15].

Tannin bersifat astringen yang memiliki kemampuan untuk membentuk makromolekul, terutama protein, kemampuan tersebut dapat mempercepat proses hemostatis, dan melalui efek astringentnya tannin bersifat sebagai vasokonstriktor. Tannin mempercepat keluarnya protein dari sel dan mengendapkan protein tersebut pada permukaan sel, juga mengurangi sekresi dan permeabilitas kapiler, kontraksi ruang antar sel, pengerasan endothelium kapiler dan kemudian membentuk lapisan pelindung kulit sehingga lapisan superfisial sel mengencang dan menyusut. Keadaan ini akan menghasilkan vasokonstriktor lokal dan kapiler $[16,17,18,19]$. Selain itu, tannin juga akan mempercepat keluarnya protein dari sel dan mengendapkan protein darah sehingga dapat menginduksi sintesis tromboksan $\mathrm{A}_{2}$ (Tromboksan $\mathrm{A}_{2}$ merupakan vasokonstriktor) yang dapat meningkatan agregasi platelet, sehingga mempercepat pembentukan sumbat platelet sementara pada pembuluh darah yang cedera.

Semakin banyak protein darah yang diendapkan oleh tannin, menyebabkan meningkatnya sintesis tromboksan $\mathrm{A}_{2}$ (meningkatnya proses vasokonstriktor) dan memudahkan trombosit mengeluarkan Adenosin Difosfat (ADP). ADP dan Tromboksan $\mathrm{A}_{2}$ mengaktifkan trombosit yang berdekatan dan menyebabkannya melekat pada trombosit semula yang sudah aktif. Hal ini menyebabkan meningkatnya agregasi trombosit, sehingga membentuk sumbat trombosit [20,21]. Selain tannin, senyawa yang berfungsi dalam proses penghentian pendarahan adalah flavonoid. Mekanisme dari flavonoid dalam penghentian pendarahan adalah dengan vasokontriksi. Vasokontriksi dapat memacu agergasi trombosit sehingga sumbat trombosit dapat terbentuk dan terjadi penyumbatan luka melalui peran bekuan darah, setelah darah tersumbat, maka darah akan berhenti [22].

Hasil uji One Way Annova pada penelitian ini menunjukkan hasil sig=0.000 yang berarti ada perbedaan signifikan karena Probabilitas yang dihasilkan kurang dari 0,01 $(\mathrm{P}<0,01)$. Dari hasil uji One Way Annova dapat ditentukan bahwa hipotesis H1 peneliti diterima. Hal ini menunjukan bahwa ekstrak etanol daun bandotan (Ageratum conyzoides L.) mampu mempengaruhi waktu penghentian pendarahan (Bleeding time) pada mencit jantan. Pada hasil uji dengan menggunakan Uji Least Significant Difference (LSD) didapatkan hasil bahwa konsentrasi $40 \%$ memiliki efektivitas terbaik dalam menghentikan pendarahan. Berdasarkan hasil analisis data, konsentrasi ekstrak daun bandotan $40 \%$ dengan kelompok kontrol positif yang diberikan obat epinefrin mempunyai efek yang sebanding dalam menghentikan pendarahan, meskipun rata-rata waktu menghentikan pendarahan oleh kelompok kontrol positif lebih cepat dari rata-rata waktu kelompok ekstrak $40 \%$.

4. Kesimpulan

Pemberian ekstrak daun bandotan (Ageratum conyzoides L.) memiliki efektivitas dalam menghentikan pendarahan pada mencit jantan (Mus musculus) yang diamati dari penurunan waktu pendarahan setelah perlakuan. Ekstrak daun bandotan (Ageratum 
conyzoides L.) memiliki efektivitas dalam menghentikan pendarahan pada mencit jantan dengan konsentrasi terbaik adalah $40 \%$.

\section{Referensi}

[1] Ismail, 2015. Faktor Yang Mempengaruhi Keputusan Masyarakat Memilih Obat Tradisional Di Gampong Lam Ujong. Idea Noursing Journal.

[2] Menteri Kesehatan Republik Indonesia, 2016. Formularium Obat Herbal Asli Indonesia. Jakarta: Menteri Kesehatan Republik Indonesia

[3] Mutschler, E., 1991. Dinamika Obat, Buku Ajar Farmakologi dan Toksikologi Edisi 5. Diterjemahkan oleh Widiarto, M.B., dan Ranti, A. S., 177. Bandung: ITB

[4] Pitojo, S. 2002. Ceplukan (Herba Berkhasiat Obat). Yogyakarta: Kanisius

[5] Dash, GK \& Murthy, PN. 2011. Wound Healing Effects of Ageratum conyzoides Linn. India: Int Journal Pharma Bio Sci, 2(2)

[6] Amadi, B.A., Duru, M.K.C. dan Agomuo, E.N. 2012. Chemical profiles of leaf, stem, root, and flower of Ageratum conyzoides. Asian Jurnal of Plant Science and Research

[7] Klatoe, J.R. Dougnon T.V., Sacramento T.I., Dandjesso C., Edorh A.P., Koudokpon H., et al. 2012. Hemostatic Potential Of The Sap Of Musa Sapientum L. (Musaceae). Journal of Applied Pharmaceutical Science Vol 02 (06).

[8] Soegijanto, Sugeng 2006. Demam Berdarah Dengue. Airlangga: University

[9] Gandasoebrata, R. 2001. Penuntun Laboratorium Klinik. Jakarta: Dian Rakyat.

[10] Sutopo, Tri. 2016. Uji Ekstrrak Etanol 70\% (piper betle) terhadap bleeding timepada mencit jantan galur swis Webster. Surakarta: UMS

[11] Putri, Zulia Ika. 2017. Efek Diuretik Ekstrak Metanol Daun Salam (Eugenia polyantha) Pada Kelinci Jantan (Oryctolagus cuniculus). Gorontalo: Universitas Negeri Gorontalo

[12] Durachim, Adang \& Dewi Astuti, 2018. Hemostatis : Bahan Ajar Teknologi Laboratorium Medik (TLM). Pusat Pendidikan Sumber Daya Manusia Kesehatan: Kementrian Kesehatan Republik Indonesia

[13] Gunawan, S.G., Setiabudy R. 2011. Farmakologi dan Terapi. Jakarta: Balai Penerbit FKUI

[14] Finkel R., Clark M.A., Cubeddu L.X., Harrey R.A., Champe P.C., 2009, Lippincott's Illustrated Review Pharmacology 4thEd. Pliladelphia: Williams \& Wilkins

[15] Hassanpour, S. N. Maheri-Sis. B Eksshratkhah, dan F. B. Mehmandar. 2011. Plants and Secondary Metanolites (Tannins). A Review Int. J. Forest, Soil and Erosion 
[16] Choong, S.K.S., Walkden, M., Kirby, R. 2000. Review : The Management of Intractable Haematuria. BJU International

[17] Davis, S.C., Perez, R. 2009. Cosmeceuticals and natural products: wound healing. Clinics in Dermatology.

[18] Libster, M. 2002. Delmar's Integrative Herb Guide for Nurse. USA: Thomson Learning Inc

[19] Mohaan, M., Gupta, A., Shenoy, V. 2011. Pharmacological Agents in Dentistry : A Review. British Journal of Pharmaceutichal Research

[20] Odokuyo, O.A., Sofidiya, M.O., Ilori, O.O., Gbededo, M.O., Ajadotuigwe, J.O., Olaleye, O.O. 2009. Hemorrhoid Therapy With Medicinal Plants. Astringency and Inhibition of Lipid Peroxidation as Key Factors. International Journal of Biological Chemistry

[21] Purnamasari, O. R. I., Arudina., dan T.I Budhy. 2012. Efek Hemostatis Ekstrak Etanol Daun Teratai (Nymphae rubra Roxb.) Pada Luka Potong Ekor Mencit (Mus musculus) 